\title{
Progress and prospects of glucosinolate pathogen resistance in some brassica plants
}

\section{Ejiroghene Ruona Evivie}

College of Life Sciences, Northeast Agricultural University, Harbin, 150030, China Department of Plant Biology and Biotechnology, Faculty of Life Sciences, University of Benin, PMB 1154, Ugbowo, Benin City, Edo State, Nigeria

\section{Matthew Chidozie Ogwu}

Department of Plant Biology and Biotechnology, Faculty of Life Sciences, University of Benin, PMB 1154, Ugbowo, Benin City, Edo State, Nigeria

School of Bioscience and Veterinary Medicine, University of Camerino, 62032 Camerino, Marche - Floristic Research Center of the Apennines, Gran Sasso and Monti della Laga National Park, San Colombo, 67021 Barisciano, L'Aquila, Italy

\section{Wei Cang}

College of Life Sciences, Northeast Agricultural University, Harbin, 150030, China

Rui Xu

College of Life Sciences, Northeast Agricultural University, Harbin, 150030, China

Jing $\mathbf{L i}^{*}$

College of Life Sciences, Northeast Agricultural University, Harbin, 150030, China

*Corresponding author. E-mail: Jing LI - lijing@neau.edu.cn

\begin{abstract}
Plants are constantly defending themselves against an array of assaults by pathogenic organisms. This has led to the evolution of precise and elaborate chemical defense systems involving glucosinolates (GSLs) in cruciferous plants. These GSLs and their hydrolysis products are biologically active and are implicated as enabling formidable plant defense processes in certain economically important members of Brassicaceae like broccoli, cabbage and mustard seed. This review provides a comprehensive report of how indole and aliphatic GSLs mitigate incidents of plant pathogenesis. By evaluating the roles of GSLs in plant-pathogen interaction of some brassica plants, this review highlights the associated mechanism that culminates in disease suppression. Moreover, seven economically important brassica pathogens were reviewed in terms of their ability to disrupt proper plant functioning as well as the mechanisms by which GSLs and their hydrolysis products in Brassica lower the susceptibility to them. Future perspectives of the application of GSLs in plant pathogen resistance using advanced molecular techniques are also discussed.
\end{abstract}

Keywords: Arabidopsis, Brassicaceae, Glucosinolates, Pathogens, Plant immunity, Secondary metabolites

\section{INTRODUCTION}

Plant biochemical defense mechanisms evolved overtime through phytochemical-mediated strategies to adapt and overcome antagonistic stress that may impair growth, development and reproduction (Dangl and Jones, 2001; Ausubel, 2005; Jones and Dangl, 2006, Chisholm et al., 2006). Some of the end products of this defense action include the production of reactive oxygen species (ROS), signal transduction, cell fortification, enzyme synthesis and production of diverse secondary metabolites. However, according to Dangl and Jones (2006), the lack of mobile defender cells and somatic adaptive immune systems ensures that plant often relies on the innate immunity of their individual cells as well as on systemic signals

\section{Article Info}

DOI:10.31018/jans.v11i2.2117

Received: May 7, 2019

Revised: June 6, 2019

Accepted: June 10, 2019

\section{How to Cite}

Evivie, E. R. et al. (2019)

Progress and prospects of glucosinolate pathogen resistance in some brassica plants. Journal of Applied and Natural Science, 11

(2): $556-567$ https:// doi.org/10.31018/

jans.v11i2.2117 
terns (Underwood, 2012). Nonetheless, the turnover of associated secondary metabolite such as glucosinolates (GSLs) is a suggestion of their roles in key interactions (Bednarek et al., 2009). For instance, the effector-triggered hypersensitive response (ET-HR) mechanism, which depends on indole and aliphatic glucosinolates, or their byproducts have been implicated in delayed programmed cell death upon Pseudomonas syringae and Hyaloperonospora arabidopsidis inoculation in aliphatic glucosinolate-deficient myb28 and myb29 plants (Johansson et al., 2014; Andersson et al., 2015). These findings confirm that glucosinolates are associated with the ET-HR and ROS pathways.

Pathogens have significant effects on plant fitness and may regulate plant population and in turn lead to considerable economic damage (Rausher, 2001). After successful penetration, pathogens may directly benefit from the active metabolism of their host to complete their life cycle by either keeping the host cells alive during colonization (biotrophic strategy) or induce host cell disintegration after infection (necrotrophic strategy). Some pathogenic fungus utilizes hemibiotrophic strategy whereby they undergo a biotrophic phase and later switch to a necrotrophic phase (Horbach et al., 2011; Huckelhoven and Panstruga, 2011; Bolton et al., 2006). Williamson et al. (2007) posited that necrotrophic pathogens pose the significant economic challenge on Brassica crops because of their ability to cause lesions on nearly all harvestable parts of the plant. No completely resistant Brassica germplasm have been recorded for most of this necrotrophic fungus (Cao et al. 2016)

As a group of thioglucosides, including tryptophan -derived indole glucosinolates (IGSLs) and methionine, derived aliphatic glucosinolates (AGSLs), glucosinolates (GSLs) are important secondary metabolites in Brassica species. This plant health promoting, sulfur and nitrogen-containing group of phytochemicals can be found in several Brassica species including cauliflower, rapeseed, cabbage, broccoli, radish, rutabaga, baemuchae, kohlrabi, turnip, black mustard, Chinese cabbage, leaf mustard, and kale. In addition, Holst and Fenwick (2003) assert that these cruciferous plants containing GSLs have made invaluable contributions to human and animal diets as additives (mustard and wasabi), leafy vegetables (cabbage, swede), and livestock feedstuffs (rapeseed, kale, turnip). They are present in different concentrations in the different parts of the plant that may provide added insights into their site-dependent expression and functions (Moussaieff et al., 2013; Bhandari et al., 2015). GSLs also perform regulatory functions in inflammation, stress response, phase I metabolism, and antioxidant activities, as well as direct antimicrobial properties (Bischoff, 2016). In the same vein, some Brassica species containing
GSLs have also been implicated in phytoremediation and biofumigation (Szczygłowska et al., 2011). Myrosinases coexist with GSLs but are stored separately in adjacent cells but mix upon sensing a pathogen attack (Redovnikov et al., 2008). The result is an hydrolysis of thioglucosidic GSLs bond to produce unstable aglucones, which decompose to various bioactive compounds, including isothiocyanates and thiocyanate with toxic effects on microorganisms, nematodes, insects and other pathogens (see Fig. 1; Lambrix et al., 2001; Burow and Wittstock, 2009; Bednarek et al., 2009; Clay et al., 2009; Wittstock and Burow, 2010; Stotz et al., 2011; Bednarek, 2012).

Some key defense mechanisms include a direct response to specific antimicrobial activities, metabolite biosynthesis, callose deposition, transcription of response genes, stomatal closure and programmed plant cell death signaling (Fig. 2). Previous workers have elucidated the roles of phytochemicals (chiefly secondary plant metabolites) in protecting plants against pathogens and pests (Cowan, 1999; Bennett and Wallsgrove, 1994). In the case of Brassica crops, they either produce phytochemicals as a component of their growth and development (i.e. inbuilt chemical barriers; structural barriers such as lignin, and pre-formed phytoanticipins such as GSLs) or de novo synthesis in response to pathogen attack or stress (phytoalexins) (Bennett and Wallsgrove, 1994).

Over the years, many studies have elucidated the GSL-triggered mechanisms by which plant immune systems respond upon attack by various pathogens (Table 1). These works suggest different operational mechanism, genes and vectors are involved in diverse GSL interactions. In addition, the indole glucosinolate biosynthesis pathway has been successfully bioengineered in Nicotiana benthamiana, a non-Brassica plant (Pfalz et al., 2011) and molecular techniques have also shown in detail how specific glucosinolates like glucoraphanin (4-methyl sulfinyl butyl GLS; 4MSB) inhibit tumor cell growth in tobacco (Mikkelsen et al., 2010). However, limited information on the effects of specific pathogens on specific Brassica plants is available. This review presents a comprehensive investigation of some of the most important pathogens, which cause considerable damage to Brassica plants. This report will also highlight studies that successfully demonstrated the mechanisms by which GSLs mitigate pathogen effects on specific Brassica species. Some insights into future considerations for potential application in experiment and field studies will also be provided in this work.

\section{Xanthomonas campestris pv. campestris} (Pammel) Dowson: Xanthomonas campestris pv. campestris, is the Gram-negative bacterium responsible for Black rot, one of the most devastating diseases of cruciferous crops 
Evivie, E. R. et al. / J. Appl. \& Nat. Sci. 11(2): 556 - 567 (2019)

Table 1. Some studies showing the effects of specific GSLs on different pathogens and/or herbivores.

\begin{tabular}{|c|c|c|c|c|}
\hline $\begin{array}{l}\text { Vectorl } \\
\text { herbivore }\end{array}$ & Pathogen/parasite & $\begin{array}{l}\text { Specific GSL type/ } \\
\text { metabolite }\end{array}$ & Results of study & Reference \\
\hline \multirow[t]{2}{*}{ Not mentioned } & $\begin{array}{lr}\begin{array}{l}\text { Colletotrichum } \\
\text { sporioides }\end{array} & \text { gloeo- } \\
\text { Penz. and Sacc. } & \end{array}$ & IGSLS & $\begin{array}{l}\text { Microbe-associated molecular pattern (MAMP)-triggered immunity } \\
\text { activates a genetically programmed cell death in the absence of the } \\
\text { functional membrane-attack complex/perforin (MACPF) domain } \\
\text { protein encoded by the Necrotic Spotted Lesion } 1 \mathrm{NSL} \text { ) gene via } \\
\text { Tryptophan (Trp)-derived secondary metabolite-mediated activation } \\
\text { of the salicylic acid (SA) pathway. }\end{array}$ & $\begin{array}{l}\text { Fukunaga et } \\
\text { al. (2017) }\end{array}$ \\
\hline & $\begin{array}{l}\text { Botrytis cinerea Pers. } \\
\text { Dickeya dadantii } \\
\text { Samson and others }\end{array}$ & IGSLS & $\begin{array}{l}\text { Enhanced accumulation of glucosinolates in response to exogenous- } \\
\text { ly applied nicotinamide adenine dinucleotide }\left(\mathrm{NAD}^{+}\right) \text {. In addition, an } \\
\text { up-regulation of the glucosinolate-responsive genes PEN2 } \\
\text { (penetration-resistance gene } 2 \text { ) and } 519 \text { CYP81F2 after direct NAD } \\
\text { treatment was observed, thus indicating NAD-specific regulation in Q } \\
\text {-treated nadC of genes are involved in glucosinolate metabolism }\end{array}$ & $\begin{array}{l}\text { Pétriacq et al. } \\
\text { (2016) }\end{array}$ \\
\hline $\begin{array}{l}\text { Cabbage looper } \\
\text { (Trichoplusia ni } \\
\text { Hubner) }\end{array}$ & Not mentioned & $\begin{array}{l}\text { Neoglucobrassicin and } \\
\text { Glucobrassicin }\end{array}$ & $\begin{array}{l}\text { Upon attack, the biosynthesis of both IGSs increased in a dose- } \\
\text { dependent manner. The IGSs and their hydrolysis products showed } \\
\text { significant inverse correlation with larval weight and survival after five } \\
\text { days of treatment. }\end{array}$ & $\begin{array}{l}\mathrm{Ku} \text { et al. } \\
(2016)\end{array}$ \\
\hline $\begin{array}{l}\text { Leaf-chewing } \\
\text { insect } \\
\text { (Mamestra } \\
\text { brassicae L.) }\end{array}$ & Not mentioned & Aliphatic GSLs & $\begin{array}{l}\text { Herbivore-induced ORA59-branch of the jasmonic acid (JA) signaling } \\
\text { pathway and rhizobacterial colonization enhances the synthesis of } \\
\text { aliphatic glucosinolates while synthesis of indole glucosinolates is } \\
\text { suppressed. }\end{array}$ & $\begin{array}{l}\text { Pangesti et } \\
\text { al. (2016) }\end{array}$ \\
\hline $\begin{array}{l}\text { Brassica } \\
\text { oleracea }\end{array}$ & $\begin{array}{l}\text { (Plectosphaerella } \\
\text { cucumerina Lindf. (W. } \\
\text { Gams.)) }\end{array}$ & IGSLs & $\begin{array}{l}\text { MYB34, MYB51, and MYB122 transcription-mediated indole glucos- } \\
\text { inolate biosynthesis via PEN2 myrosinase }\end{array}$ & $\begin{array}{l}\text { Frerigmann } \\
\text { et al. }(2016)\end{array}$ \\
\hline \multirow{9}{*}{$\begin{array}{l}\text { Pea aphids } \\
\text { (Acyrthosiphon } \\
\text { pisum Harris) } \\
\text { Green peach } \\
\text { aphids (Myzus } \\
\text { persicae) }\end{array}$} & $\begin{array}{l}\text { Parasitic dodder vines } \\
\text { (Cuscuta gronovii } \\
\text { Willd.) }\end{array}$ & Aliphatic GSLs, IGSLs & $\begin{array}{l}\text { Elevated concentration of aliphatic and indole glucosinolates lowered } \\
\text { parasitism by suppressing cyp } 79 B 2 \text { cyp } 79 B 3 \text { factors }\end{array}$ & $\begin{array}{l}\text { Smith et al. } \\
(2016)\end{array}$ \\
\hline & $\begin{array}{l}\text { Escherichia coli } \\
\text { (Migula), Pseudomo- } \\
\text { nas aeruginosa } \\
\text { (Schroeter) Migula, } \\
\text { Staphylococcus aure- } \\
\text { us (Rosenbach) and } \\
\text { Listeria monocyto- } \\
\text { genes (Murray) Pirie }\end{array}$ & $\begin{array}{l}\text { Allylisothiocyanate (AITC) } \\
\text { and 2- phenylethylisothio- } \\
\text { cyanate (PEITC) }\end{array}$ & $\begin{array}{l}\text { Altered the membrane properties of the bacteria by decreasing their } \\
\text { surface charge and compromising the integrity of the cytoplasmatic } \\
\text { membrane with consequent potassium leakage and propidium iodide } \\
\text { uptake }\end{array}$ & $\begin{array}{l}\text { Borges et al. } \\
(2015)\end{array}$ \\
\hline & $\begin{array}{l}\text { Xanthomonas cam- } \\
\text { pestris pv. Campestris } \\
\text { (Dowson) Dye and } \\
\text { others, Pseudomonas } \\
\text { syringae pv. Maculico- } \\
\text { la (McCulloch) Dye } \\
\text { and others, Alternaria } \\
\text { brassicae and Sclero- } \\
\text { tinia scletoriorum }\end{array}$ & $\begin{array}{l}\text { 2-Propenyl (SIN) } \\
\text { 3-Methylsulphinylpropyl } \\
\text { (GIB) } \\
\text { 4-Methylsulphinylbutyl } \\
\text { (GRA) } \\
\text { 2-Hydroxy-3-butenyl } \\
\text { (PRO) } \\
\text { 3-Butenyl (GNA) } \\
\text { 4-Pentenyl (GBN) } \\
\text { 4-Methylthiobutyl (GER) } \\
\text { 4-Hydroxybenzyl (SNB) 2 } \\
\text {-Phenylethyl (GST) } \\
\text { Indole-3-ylmethyl (GBS) }\end{array}$ & $\begin{array}{l}\text { A dose-dependent inhibition of all studied pathogens was demon- } \\
\text { strated. }\end{array}$ & $\begin{array}{l}\text { Sortelo et al. } \\
(2014)\end{array}$ \\
\hline & Botrytis cinerea (Pers.) & $\begin{array}{l}\text { Allyl-isothiocyanate } \\
\text { (AITC) }\end{array}$ & $\begin{array}{l}\text { The AITC treatment reduced the decay caused by the pathogen by } \\
\text { over } 47.4 \% \text { up to } 91.5 \% \text {, significantly different from the untreated } \\
\text { fruit. Total phenolic content and antioxidant capacity estimated in } \\
\text { treated and untreated strawberries showed no significant difference } \\
\text { between control and AITC treated fruit. }\end{array}$ & $\begin{array}{l}\text { Ugolini et al. } \\
(2014)\end{array}$ \\
\hline & $\begin{array}{l}\text { Alternaria brassicae, } \\
\text { Hyaloperonospora } \\
\text { brassicae (Gaum.) } \\
\text { Goker and others, and } \\
\text { Albugo candida (Pers.) } \\
\text { Roussel. }\end{array}$ & Aliphatic GSLs & $\begin{array}{l}\text { Exposure of plants to elevated concentration of } \mathrm{CO}_{2}(550 \mathrm{ppm}) \\
\text { revealed lower incidence and severity of Alternaria blight while white } \\
\text { rust infection increased. There was an increase in the concentration } \\
\text { of total glucosinolates (GSs) under free-air } \mathrm{CO}_{2} \text { enrichment (FACE) } \\
\text { in plants grown under elevated } \mathrm{CO}_{2} \text {, but a decrease in their diversity. }\end{array}$ & $\begin{array}{l}\text { Mathur et al. } \\
(2013)\end{array}$ \\
\hline & Broad spectrum & AITC & $\begin{array}{l}\text { AITC-induced stomatal closure requires methyl jasmonate (MeJA) } \\
\text { priming but not abscisic acid (ABA) priming, resulting in suppression } \\
\text { of water loss and invasion of fungi through stomata }\end{array}$ & $\begin{array}{l}\text { Khokon et al. } \\
\text { (2011) }\end{array}$ \\
\hline & $\begin{array}{l}\text { Colletotrichum } \\
\text { gloeosporioides and } \\
\text { Colletotrichum orbicu- } \\
\text { lare (Berk. and Mont.) } \\
\text { Arx }\end{array}$ & IGSLS & $\begin{array}{l}\text { The Arabidopsis indole glucosinolate pathway restricts entry of the } \\
\text { non-adapted anthracnose fungi only when these pathogens employ } \\
\text { hyphal tip-based entry (HTE). Arabidopsis mutants defective in indole } \\
\text { glucosinolate biosynthesis or metabolism support the initiation of post } \\
\text {-invasion growth of non-adapted Colletotrichum gloeosporioides and } \\
\text { Colletotrichum orbiculare }\end{array}$ & $\begin{array}{l}\text { Hiruma et al. } \\
(2010)\end{array}$ \\
\hline & $\begin{array}{l}\text { Escherichia coli, } \\
\text { Pseudomonas aeru- } \\
\text { ginosa, Listeria mono- } \\
\text { cytogenes and Staphy- } \\
\text { lococcus aureus }\end{array}$ & $\begin{array}{l}\text { Allylisothiocyanate, } \\
\text { Benzylisothiocyanate and } \\
2- \\
\text { phenylethylisothiocya- } \\
\text { nate }\end{array}$ & $\begin{array}{l}\text { All isothiocyanates were more effective in inhibiting pathogen growth } \\
\text { than phenolics. They inhibited the in vitro growth of the Gram- } \\
\text { negative and Gram-positive pathogenic bacteria }\end{array}$ & $\begin{array}{l}\text { Saavedra et } \\
\text { al. (2010) }\end{array}$ \\
\hline & 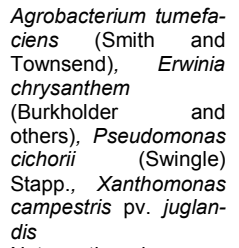 & $\begin{array}{l}\text { Aliphatic, aromatic and } \\
\text { idolyl GSL hydrolysis } \\
\text { products }\end{array}$ & $\begin{array}{l}\text { The isothiocyanates were the most effective antibacterial compo- } \\
\text { nents, showing a dose-dependent effect. 2-phenylethylisothiocyanate } \\
\text { and sulphoraphane showed the highest inhibitory effects. }\end{array}$ & $\begin{array}{l}\text { Aires et al. } \\
(2009)\end{array}$ \\
\hline $\begin{array}{l}\text { Leaf-chewing } \\
\text { insect } \\
\text { (Mamestra } \\
\text { brassicae L.) }\end{array}$ & Not mentioned & Aliphatic GSLs & $\begin{array}{l}\text { Aliphatic GSLs biosynthesis solely regulated by myb28/myb29 } \\
\text { transcription factors. Myb28/Myb29 double mutant was devoid of any } \\
\text { aliphatic GSLs. }\end{array}$ & $\begin{array}{l}\text { Beekwilder et } \\
\text { al. (2008) }\end{array}$ \\
\hline $\begin{array}{l}\text { Polyphagous } \\
\text { aphid (Myzus } \\
\text { persicae Sulzer) }\end{array}$ & Not mentioned & IGSLS & $\begin{array}{l}\text { IGSLs biosynthesis pathway was mediated by } C Y P 79 B 2 \text { and } \\
\text { CYP79B3 genes }\end{array}$ & $\begin{array}{l}\text { Kus'nierczyk } \\
\text { et al. (2007) }\end{array}$ \\
\hline
\end{tabular}




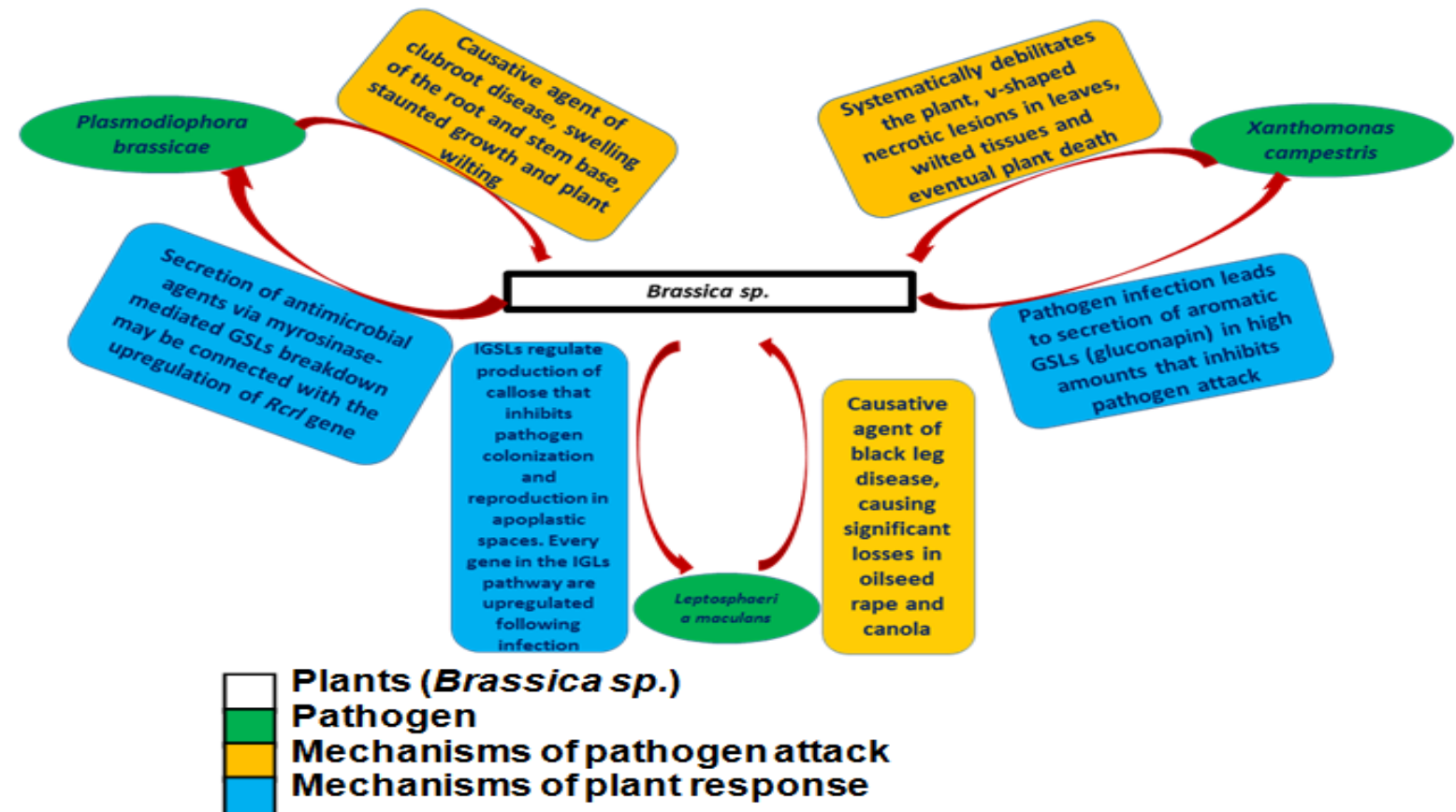

Fig. 1. GSLs and hydrolysis products' response mechanisms to attacks by $X$. campestris, $P$. brassicae and $L$. maculena.

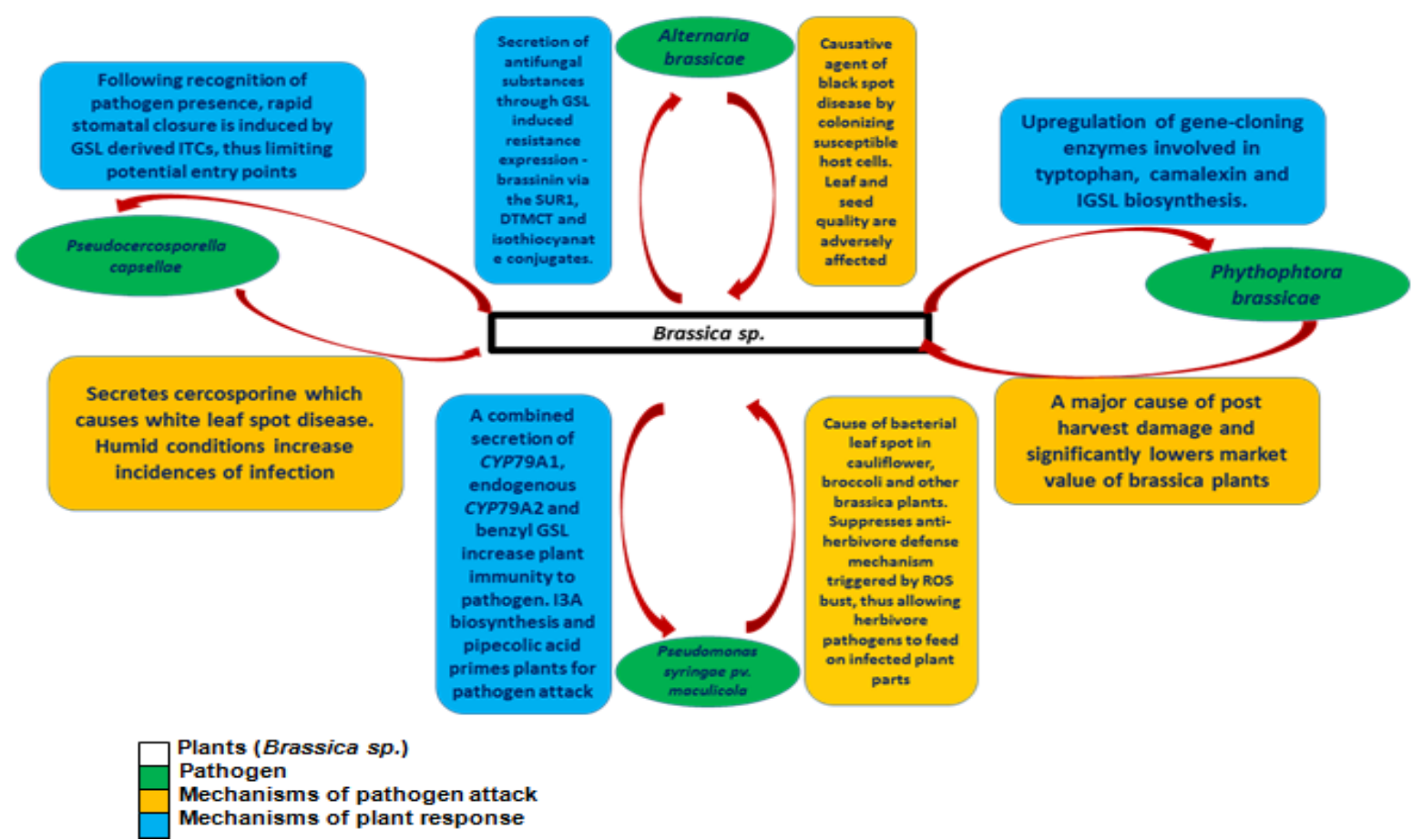

Fig. 2. GSLs and hydrolysis products' response mechanisms to attacks by $P$. maculicola, $A$. brassicae, $P$. capsellae and L. maculans.

worldwide especially Brassica oleracea var. capitata and $B$. rapa ssp. rapa L. in warm and humid climate (Dias et al., 2010; Velasco et al., 2013; Vicente and Holub, 2013). The bacterium is a seed-borne pathogen, as well as transmitted through infection or natural openings (Goss et al., 2017). The systemic vascular disease debilitates the plant, thus favoring the attack of other pathogens but even in mild attack, can cause several V-shaped necrotic lesions on leaves, which decrease the quality of the product for fresh market (Velasco et al., 2013). Symptoms include yellow lesions, wilted tissue, necrosis, defoliation and plant death (Fig. 3).

The roles of GSLs and their respective hydrolysis products (benzyl isothiocyanate, 2-phenyl ethyl 


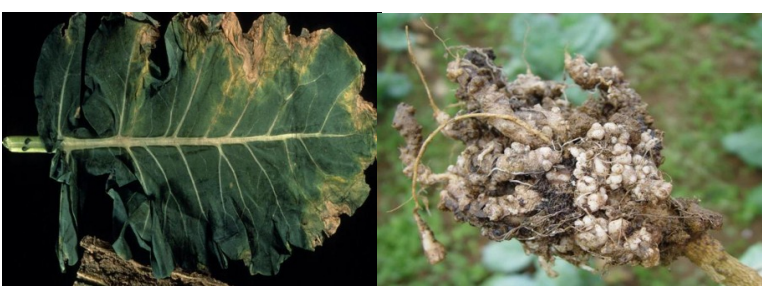

Fig. 3. Black rot caused by Fig. 4. Clubbing of BrassiXanthomonas campestris ca oleraceae var. capitata pv. Campestris on turnip root caused by Plasmodi(Brassica rapa ssp. rapa ophora brassicae

L.). Source: Mullen (2012) Source: Holmes (2003).

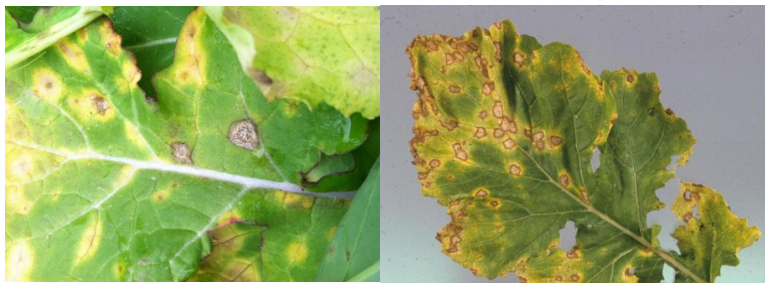

Fig. 5. A Brassica plant Fig. 6. Foliar lessons on infected by blackleg dis- turnip (Brassica rapa ssp. ease caused by Lepto- rapa) caused by Pseudosphaeria maculans cercosporella capsellae Source: Pscheidt and Source: Holmes (2010). Ocamb (2019).

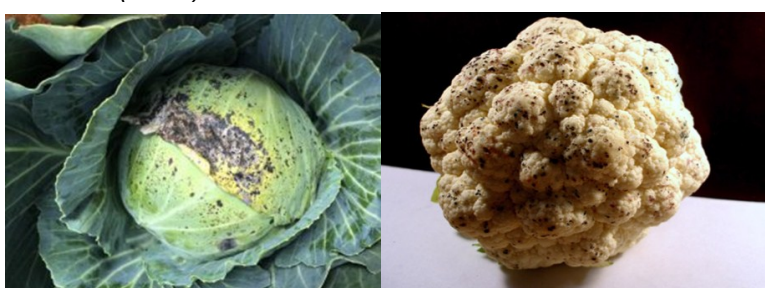

Fig. 7. Black spot of cab- Fig. 8. Leaf spot of Caulibage caused by Alternaria flower caused by Pseudobrassicae Source: Wells (2018). monas syringae pv. maculicola Source: Lazarev (2009).

isothiocyanate and sulforaphane), against $X$. campestris infection on Brassica plants have been highlighted by the report of Aires et al. (2011). They concluded that GSLs play complex roles disease resistance, particularly in the early growth stages when the young plants are in metabolic flux. Nonetheless, they successfully showed the susceptibility of Brassica to $X$. campestris is generally higher in Brassica species with lower contents of aromatic GSLs and 4-methyl sulfinyl butyl (glucoraphanin). These compounds are effective inhibitors of $X$. campestris in vitro. More so, experiment results of Velasco et al. (2013) showed that butl-3-enylglucosinolate and isothiocyanate have direct antimicrobial activities on $X$. campestris. Their results demonstrated that gluconapin and its ITC possess antibacterial effect on the development of $X$. campestris and this effect strongly correlate with the concentration of the above compounds.

Plasmodiophora brassicae Woronin: Plasmodiophora brassicae is the causative agent of club rot disease that affect the root and lower stem of Brassica crops such as the Canadian canola (Brassica napus L.) and cabbage Brassica oleraceae var. capitata L. (Fig. 4). It is a soilborne, obligate, and biotrophic pathogen that is capable of causing significant yield losses (Dixon, 2009). The pathogen causes the root and stem base to swell and form characteristic clubs, which inhibit xylem and phloem roles, stunt the growth of the plant and wilting. After weeks of infection, the clubbed root, weakening the support of the plant. (Voorrips, 1995).

$P$. brassicae influence glucosinolate levels in both root and aerial tissues during primary, secondary and mature gall formation stage disease development (Islam and Guest, 2010). In the opinion of Voorrips (1995), the evidence of a correlation between IGSL content and club root susceptibility is conflicting because no relation between IGSL content and clubroot resistance has been found. He opined that although the auxin production from IGSL is somewhat important in clubroot development, the processes occurring during pathogenesis, the mechanisms responsible for resistance were unclear. However, Islam and Guest (2010) found that GSLs levels remain unchanged in aerial tissues but significantly increased (1.5 times) in root tissues during symptom development. The concentration difference might implicate a role for GSL in $P$. brassicae pathogenesis.

More so, Song et al. (2016) reported a myrosinase -mediated breakdown of GSLs to be one of the identified biological processes in resistant samples where they were up-regulated for hostdefense responses. Their results implicate several phytoalexins as putatively deriving from the GSL metabolism in $B$. rapa roots carrying Rcr1 (the club root resistant gene) upon $P$. brassicae infection, which suggest the possibility for antimicrobial agents via the GSL-myrosinase metabolism pathway. Recently, Zhao et al. (2017) found that in the response of $A$. thaliana to $P$. brassicae infection, the expression of GSL genes and terpenoid biosynthesis significantly increased in the metabolism pathway. Further study may be required to elucidate the resultant pathway in Brassica crops.

Leptosphaeria maculans (Sowerby) Karst: This hemibiotrophic fungal pathogen is the causal agent of blackleg disease in B. napus L. (canola, oilseed rape), which causes a significant global yield loss (Becker et al., 2017). B. napus is the second-highest produced oilseed crop worldwide and is under constant threat of the blackleg disease (Fitt et al., 2006). This underscores the economic effects of $L$. maculans, which affects the stems and leaves of Brassica plants (Fig. 5).

According to Hiruma et al. (2013), IGSLs are required for resistance against hemibiotrophic fungi. However, their role in the B. napus - L. maculans 
pathosystem was unclear at the time. Considering that IGSLs promote the production of callose that likely prevents $L$. maculans colonization and reproduction in apoplastic spaces within cotyledons thereby confering resistance on $B$. napus (Becker et al. 2017). This agrees with Aist and Bushnell (1991), who proposed that callose deposition is a conserved defense response in plants that is controlled by GSL metabolism through acting as a physical barrier in the cell wall. Data from Becker et al. (2017) also showed activation of the complete IGSL biosynthetic pathway in resistant $B$. napus cotyledons inoculated with $L$. maculans. This confirms the previous study by Clay et al. (2009) who stated that in resistant hosts, every gene of the IGSL biosynthetic pathway was upregulated following $L$. maculans infection, whereas in the susceptible genotype, several genes required for IGSL production were downregulated during infection. Future investigation may be directed at exposing specific interactions within the callose of major Brassica that act under stress conditions from L. maculans to promote defense (Fig. 4).

Pseudocercosporella capsellae (Ellis and
Everh.) Deighton: Pseudocercosporella capsellae causes white leaf spot across a wide range of Brassica plants including oilseed, vegetable condiment and forage Brassicas worldwide (Fig. 5; Crossan, 1954; Deighton, 1973; Koike et al., 2007). P. capsellae produces a purple-pink coloured toxin called cercosporin, which has been implicated in white leaf spot disease initiation in brassica crops (Gunasinghe et al., 2016). P. capsellae may be carried across seasons within thick-walled mycelium on crop debris and produces conidia when the weather is favourable. Conidia infect plants causing white or pale beige lesions on leaves. Infections are favoured by wet weather conditions (Petrie et al., 1985; Barbetti and Khangura, 2000).

Several GSL-derived ITCs induce stomatal closure in $A$. thaliana in a dose-dependent manner (Hossain et al., 2013; Khokon et al., 2011). More so, rapid stomatal closure occurs in resistant $B$. carinata following recognition of pathogen presence, a characteristic considered a winning preinvasive defence barrier developed by plants (Ton et al., 2009). By limitation potential entry ports by resistant $B$. carinata, this appears to be a major mechanism of resistance against $P$. capsellae. Hence, efforts geared at elucidating the phytochemicals associated with this structuralresistant response may characterize future research (Fig. 6).

Alternaria brassicae (Schwein) Wiltshire: Black spot disease of some Brassica crops like broccoli, oil seed rape and cabbage is caused by the fungus Alternaria brassicae (Fig. 7). This facultative parasite colonizes susceptible hosts as well as dead plant material secreting host-specific toxins. This disease results in a considerable reduction of both yield and seed quality (Sotelo et al., 2014). A. brassicae is the prime causative agent of Alternaria blight disease, which affects most Brassica crops globally, causing economic losses with no proven source of transferrable resistance in any of its hosts. In tropical regions, this pathogen is most destructive in the wet season (Meena et al., 2010).

The report of Giri et al. (2013) suggested that the production of antifungal substance(s) in resistant $B$. juncea leaves was responsible for reduced infection by Alternaria brassicae. This includes GSLs that affect the differential expression of resistance across different plant species, lines as well as cultivars of the same species or within different tissues of a plant (Osbourn, 1996). The antifungal byproducts are not formidable in resistance of these pathogens (Meena et al., 2010, Zhou et al., 2002), however, they remain a key defense system in many Brassica plants. GSLs and their hydrolysis products have also been shown previously to have antimicrobial properties (Tierens et al., 2001). Recently, more specific pathways of this antifungal mechanism were reported by Klein and Sattely (2017). These researchers identified some key enzymes required for the synthesis of the parent phytoalexin of Brassica plants called Brassinin from well-studied GSLs. Some of the brassinin-type phytoalexins may be more tightly linked to the biosynthetic pathway of IGSLs. The carbon-sulfur lyase SUR1 processes cysteine-isothiocyanate conjugates, as well as the S-methyltransferase DTCMT that methylates the resulting dithiocarbamate, together completing a pathway to brassinin. Also, the $\beta$ glucosidase BABG that is present in Brassica rapa but absent in Arabidopsis was shown by these researchers to act as a myrosinase and may be a determinant of plants that synthesize phytoalexins from IGSLs.

Phytophthora brassicae De Cock and Man in't Veld: Phytophthora brassicae is an economic and notorious oomycete pathogen. It has a narrow host range restricted to Brassica plants such as Chinese cabbage (B. rapa subsp. pekinensis), Brussels sprouts $(B$. oleracea var. gemmifera) and rutabaga ( $B$. napus var. napobrassica) (Semb, 1971, Fagertun and Semb, 1986). P. brassicae is responsible for post-harvest damage that lowers the marketability of cabbage to around $90 \%$ losses (Fagertun, 1987, Mauch et al, 2009). P. brassicae is one of the few Phythophthora species that infect Arabidopsis plant both naturally and under laboratory conditions (Koch and Slusarenko, 1990).

The susceptibility of the double mutant pen2-1 pad3-1, demonstrates that both camalexin and product of IGSL hydrolysis are important for 
$P$. brassicae disease resistance in Brassica (Schlaeppi et al., 2010). Transcript analysis from Schlaeppi et al. (2008) showed that genes encoding enzymes involved in tryptophan, camalexin and IGSL biosynthesis coordinate induced response to $P$. brassicae. On the other hand, the double mutant cyp79B2 cyp79B3 is highly susceptible to $P$. brassicae as it is unable to convert tryptophan into indole-3-acetaldoxime (IAOx), the precursor of camalexin and IGSLs (Zhao et al. 2002; Wang et al. 2013a,b). These authors also opined that the susceptibility of the double mutant cyp79b2cyp79b3 to Phytophthora capsici could be attributed to the deficiency of IGSLs and camalexin, thus IGSLs confer resistance against $P$. brassicae. $P$. brassicae disease resistance may be established by the sequential activity of phytoanticipin IGSL and phytoalexin camalexin (Fig - No figure yet.).

Pseudomonas syringae pv. Maculicola (McCullock) Young, Dye and Wilke: Pseudomonas syringae pv. maculicola (PSM) causes bacterial leaf spot in cauliflower, broccoli, brussels sprouts and other Brassicas (Fig. 8; Young, 2010; Sotelo et al., 2014). GSLs interactions trigger plant immune response against PSM. Brader et al. (2006) showed that Arabidopsis, which expresses the sorghum gene CYP79A1, endogenous CYP79A2 gene or benzyl GSL respectively, showed increased resistance towards PSM. Using a series of physiological and genetic tools, Groen et al. (2015) showed that PSM enhances the feeding of infected plant parts by the herbivore, Scaptomyza flava partly by suppressing anti-herbivore defense mechanisms triggered by ROS burst.

Stahl et al. (2016) showed that indol-3ylmethylamine (I3A) was one of the three major accumulating compounds and is also produced via IGSL breakdown by pathways dependent and independent of the myrosinase PEN2. Their report also showed that salicylic acid defense hormone produce I3A at the expense of its precursor indol3-ylmethylglucosinolate (I3M), and the SAR regulator pipecolic acid primes plants for enhanced PSM-induced activation of distinct branches of indolic metabolism. The report of Jiang et al. (2016) suggest the biosynthesis of GSL from tryptophan and aliphatic GSL biosynthesis side chain may be triggered following PSM infection. More so, differential co-expression is a common phenomenon during plant attack (Hsu et al., 2015 Gaiteri et al., 2014). These findings put together suggest the existence of an effective pathway by which GSLs and their metabolites may be manipulated for formidable defense response to bacterial pathogens such as PSM (Fig. 8).

Some future perspectives: The practical application of GSLs induced pathogen resistance response in Brassica will culminate in enhanced crop yield and preserve biodiversity. In plant breeding, the above techniques may be applied to propagate resistant varieties by exploiting individual and plant part based GSL concentration. Although, the signaling pathways involved in regulating GSL biosynthesis are unknown in some Brassica crops, which merit further investigations to advance our understanding in this regard. According to Xu et al. (2016), more omics studies will elucidate how antimicrobial activities of GSL biosynthesis can be linked with the apoptotic stimulation of programmed cell death in major fungal pathogens. No doubt, this would provide insights on the development of a new range of potent fungicides and fungal-based drugs (Shlezinger et al., 2011). The GSL biosynthesis product, 4methylsulfinylbutyl isothiocyanate (sulforaphane) does not only activate defense in naïve tissues but provide protection against virulent isolates (Andersson et al., 2015). This suggests that GSL byproducts products are involved in cell-to-cell signaling and are prime bacteriostatic molecules albeit their applications warrant more in-depth studies. Furthermore, the findings of Zhang et al. (2016) suggests that directly searching for resistance loci may not be the best approach at improving resistance in Brassica to necrotrophic pathogen, rather it may be necessary to have a broader perspective of the effects of resistance loci.

\section{Conclusion}

In future, the measuring of plant response to pathogen using transcriptional approach is likely to be more available, which will permit the analysis of large scale sizable expression data with a view to achieving more robust results. In the meantime, the flourish of transcriptional data allows us to answer specific biological questions in the context of differential co-expression. For instance, the comparative analysis of differential co-expression during plant immune responses to different pathogens is an important topic. Differential coexpression analysis can boost the study of plant immune response-related transcriptomics and provide new insights into deciphering the molecular mechanisms of plant-pathogen interactions (Jiang et al., 2016). More qualitative studies has the potential to give further insights into the synergistic effects of ROS and GSL metabolites in view of improving plant immunity (Groen et al., 2015; Groen et al., 2013; Gloss et al., 2014).

In conclusion, studies reported in this review suggest diverse complex perspectives of how aliphatic and IGSLs interact to confer immunity to plants using the model plant, Arabidopsis thaliana as well as in some Brassica crops. The trend thus far clearly shows that our view of GSLs have tremendously improved over the years. Despite advances in recent years, much is yet to be known and 
understood as to how GSLs and their hydrolysis products interact with other non-toxic plant components and plant parts. It is anticipated that more molecular (especially "-omics") studies will pave way for more effective strategies aimed at developing more resistant, tolerant and high yielding plants. Further applications of these studies in enhancing food security are also needed as the global population is projected to soar in the next twenty years and global issues such as climate change are now receiving a more synergistic and strategic response from several governments. It is anticipated that these considerations will give GSL research a more holistic application in the biotechnology, food, pharmaceutical and biomedical industries.

\section{ACKNOWLEDGEMENTS}

This work was supported by the National Natural Science Foundation of China (NSFC) 31370334, and Science Foundation of Heilongjiang Province JJ2017ZR0164.

\section{REFERENCES}

1. Aires, A., Dias, C.S.P., Carvalho, R., Oliveira, M.H., Monteiro, A.A., Simoes, M.V., Rosa, E.A.S., Bennett, R.N. and Saavedra, M.J. (2011). Correlations between disease severity, glucosinolate profiles and total phenolics and Xanthomonas campestris pv. campestris inoculation of different Brassicaceae. Scientia Horticulturae, 129:503-510. DOI : 10.1016/ j.scienta.2011.04.009.

2. Aires, A., Mota, V.R., Saavedra, M.R., Monteiro, A.A., Simones, M., Rosa, E.A.S. and Bennett, R.N. (2009). Initial in vitro evaluations of the antibacterial activities of glucosinolate enzymatic hydrolysis products against plant pathogenic bacteria. Journal of Applied Microbiology, 106: 2096-2105. DOI: 10.1111/j.1365-2672.2009.04181.x.

3. Aist, J.R., and Bushnell, W.R. (1991). Invasion of plants by powdery mildew fungi, and cellular mechanisms of resistance. In: Cole, G.T. and Hoch, H.C. (eds). The fungal spore and disease initiation in plants and animals. Plenum Press, New York, pp 321 -345 .

4. Andersson, M. X., Nilsson, A. K., Johansson, O. N., Boztaş, G., Adolfsson, L. E., Pinosa, F. and Hamberg, M. (2015). Involvement of the electrophilic isothiocyanate sulforaphane in Arabidopsis local defense responses. Plant Physiology, 167(1):251261. DOI: $10.1104 /$ pp.114.251892.

5. Ausubel, F. M. (2005). Are innate immune signaling pathways in plants and animals conserved? Nature Immunology, 6:973-979. DOI: 10.1038/ni1253.

6. Barbetti, M.J. and Khangura, R, (2000). Fungal Diseases of Canola in Western Australia. Bulletin 4406a. Western Australia, Australia: Department of Agriculture and Food.

7. Becker, M.G., Zhang, X., Walker, P.L., Wan, J.C., Millar, J.L., Khan, D., Granger, M.J., Cavers, J.D., Chan, A.C., Fernando, W.G.D. and Belmonte, M.F. (2017). Transcriptome analysis of the Brassica napus - Leptosphaeria maculans pathosystem identifies receptor, signalling and structural genes underlying plant resistance. The Plant Journal, 90(3):573-586. DOI: $10.1111 /$ tpj.13514.

8. Bednarek, P. (2012). Chemical warfare or modulators of defence responses - the function of secondary metabolites in plant immunity. Current Opinions in Plant Biology, 15:407-414. DOI: 10.1016/ j.pbi.2012.03.002

9. Bednarek, P., Pislewska-Bednarek, M., Svatos, A., Schneider, B., Doubsky, J., Mansurova, M., Humphry, M., Consonni, C., Panstruga, R., SanchezVallet, A., Molina, A., and Schulze-Lefert, P. (2009). A glucosinolate metabolism pathway in living plant cells mediates broadspectrum antifungal defense. Science, 323:101-106. DOI: 10.1126/science. 1163732

10.Beekwilder J, van Leeuwen W, van Dam NM, Bertossi M, Grandi V, et al. (2008). The impact of the absence of aliphatic glucosinolates on insect herbivory in Arabidopsis. PLOS ONE 3(4):e2068. DOI:10.1371/journal.pone.0002068.

11.Bennett, R. N., and Wallsgrove, R. M. (1994). Secondary metabolites in plant defence mechanisms. New Phytologist, 127:617-633.

12.Bhandari, S.R., Jo, J.S. and Lee, J.G. (2015). Comparison of glucosinolate profiles in different tissues of nine brassica crops. Molecules, 20: 15827-15841. DOI:10.3390/molecules200915827.

13.Bischoff, K.L. (2016). Chapter 40 - Glucosinolates, In: Nutraceuticals. Gupta, R.C. (ed). Academic Press. pp 551-554. DOI: https://doi.org/10.1016/B978-0-12802147-7.00040-1.

14.Bolton, M. D., Thomma, B. P. and Nelson, B. D. (2006). Sclerotinia sclerotiorum (Lib.) de Bary: biology and molecular traits of a cosmopolitan pathogen. Molecular Plant Pathology, 7(1):1-16. DOI: 10.1111/j.1364-3703.2005.00316.x.

15.Borges, A., Abreu, A.C., Ferreira, C., Saavedra, M.J., Simões, L.C. and Manuel Simões, M. (2015). Antibacterial activity and mode of action of selected glucosinolate hydrolysis products against bacterial pathogens. Journal of Food Science and Technology, 52 (8):4737-4748, DOI: 10.1007/s13197-014-1533-1.

16.Brader, G., Mikkelsen, M.D., Halkier, B.A. and Palva, E.T. (2006). Altering glucosinolate profiles modulates disease resistance in plants. The Plant Journal, 46:758-767. DOI: 10.1111/j.1365313X.2006.02743.x.

17.Burow, M., and Wittstock, U. (2009). Regulation and function of specifier proteins in plants. Phytochemistry. Reviews, 8:87-99. DOI: https://doi.org/10.1007/ s11101-008-9113-5.

18.Cao, J.Y., Xu, Y.P. and Cai, X.Z. (2016). TMT-based quantitative proteomics analyses reveal novel defense mechanisms of Brassica napus against the devastating necrotrophic pathogen Sclerotinia sclerotiorum. Journal of Proteomics, 143: 265-277. DOI: https://doi.org/10.1016/j.jprot.2016.03.006

19.Chisholm, S. T., Coaker, G., Day, B. \& Staskawicz, B. J. (2006). Host-microbe interactions: shaping the evolution of the plant immune response. Cell, 124:803-814. DOI: 10.1016/j.cell.2006.02.008.

20.Clay, N.K., Adio, A.M., Denoux, C., Jander, G., and Ausubel, F.M. (2009). Glucosinolate metabolites required for an Arabidopsis innate immune response. Science, 323:95-101. DOI: 10.1126/ science. 1164627.

21.Cowan, M.M. (1999). Plant products as antimicrobial 
agents. Clinical Microbiology Reviews, 12: 564-582.

22.Crossan, D.F, (1954). Cercosporella leafspot of crucifers. North Carolina Agricultural Experiment Station Technical Bulletin, 109: 23

23.Dangl, J.L. \& Jones, J.D.G. (2001). Plant pathogens and integrated defence responses to infection. $\mathrm{Na}$ ture, 411:826-833. DOI: 10.1038/35081161.

24.Deighton, F.C. (1973). Studies on Cercospora and allied genera. Mycological Papers, 133:42-46.

25.Dias, J.S., Nogueira, P. and Corvo, L. (2010). Evaluation of a core collection of Brassica rapa vegetables for resistance to Xanthomonas campestris pv. campestris. African Journal of Agricultural Research, 5(21):2972-2980.

26.Dixon, G.R. (2009). Plasmodiophora brassicae in its environment. Journal of Plant Growth and Regulations, 28:212-228. DOI: http://dx.doi.org/10.1007/ s00344-009-9098-3.

27.Fagertun, L. (1987). Lagringspatogener på hvitkål og kålrot. Utbredelse, patogenitet og bekjempelse (Postharvest pathogens on cabbage and rutabaga). Agricultural University of Norway.

28.Fagertun, L. and Semb, L. (1986). Sykdommer på kål og kålrot, Phytophthora- råte [Diseases on cabbage and rutabaga, Phytophthora-rot]. Norsk Landbruk, 105(8):16-17.

29.Fitt, B.D.L., Brun, H., Barbetti, M.J. and Rimmer, S.R. (2006). Worldwide importance of phoma stem canker (Leptosphaeria maculans and L. biglobosa) on oilseed rape (Brassica napus). European Journal of Plant Pathology, 114:3-15. DOI: https:// doi.org/10.1007/s10658-005-2233-5.

30.Frerigmann H., Pislewska-Bednarek M., SanchezVallet A., Molina A., Glawischnig E., Gigolashvili T., and Bednarek P. (2016). Regulation of pathogentriggered tryptophan metabolism in Arabidopsis thaliana by MYB transcription factors and indole glucosinolate Conversion Products. Molecular Plant, 9:682695. DOI: 10.1016/j.molp.2016.01.006.

31.Fukunaga, S., Sogame, M., Hata, M., SingkaravanitOgawa, S., Pislewska-Bednarek, M., OnozawaKomori, M., Nishiuchi, T., Hiruma, K., Saitoh, H., Terauchi, R., Kitakura, S., Inoue1, Bednarek, Y.P., Schulze-Lefert, P. and Takano, Y. (2017). Dysfunction of Arabidopsis MACPF domain protein activates programmed cell death via tryptophan metabolism in MAMP-triggered immunity. The Plant Journal, 89:381 -393. DOI:10.1111/tpj.13391.

32.Gaiteri, C., Ding, Y., French, B., Tseng, G. C. and Sibille, E. (2014). Beyond modules and hubs: the potential of gene coexpression networks for investigating molecular mechanisms of complex brain disorders. Genes, Brain and Behavior, 13:13-24.DOI: https://doi.org/10.1111/gbb.12106.

33.Giri, P., Taj, G., and Kumar, A. (2013). Comparison of artificial inoculation methods for studying pathogenesis of Alternaria brassicae (Berk.) Sacc on Brassica juncea (L.) Czern.(Indian mustard). African Journal of Biotechnology, 12(18): 2422-2426. DOI: 10.5897/AJB12.2803.

34.Gloss, A.D., Vassao, D.G., Hailey, A.L., Nelson Dittrich, A.C., Schramm, K., Reichelt, M., Rast, T.J.,Weichsel, A., Cravens,M.G., Gershenzhon,J.,Monfort, W.R. and Whiteman, N.K. (2014). Evolution in an ancient detoxification pathway is coupled with a transition to herbivory in the Drosophilidae. Molecular Biology and. Evolution, 31: 2441-
2456. DOI: 10.1093/molbev/msu201.

35.Goss, M., Mafongo, P., Gubba, A. and Sam, T. (2017). Black Rot (Xanthomonas campestris pv. campestris) control in field grown cabbage (Brassica oleracea var. Sugar Loaf) with Moringa oleifera extracts. International Journal of Plant \& Soil Science, 18(2): 1-11. DOI: 10.9734/IJPSS/2017/29850.

36.Groen, S.C., Humphrey, P.T., Chevasco, D., Ausubel., F.M., Pierce, N.E. and Whiteman, N.K. (2015). Pseudomonas syringae enhances herbivory by suppressing the reactive oxygen burst in Arabidopsis. Journal of Insect Physiology, DOI: http:// dx.doi.org/10.1016/j.jinsphys.2015.07.011

37.Groen, S.C., Whiteman, N.K., Bahrami, A.K., Wilczek, A.M., Cui, J., Russell, J.A., CibrianJaramillo, A., Butler, I.A., Rana, J.D., Huang, G.H., Bush, J., Ausubel, F.M. and Pierce, N.E. (2013). Pathogen-triggered ethylene signaling mediates systemic induced susceptibility to herbivory in Arabidopsis. Plant Cell, 25(11):4755- 4766. DOI:10.1105/ tpc.113.113415.

38.Gunasinghe, N., You, M. P., Clode, P. L., and Barbetti, M. J. (2016). Mechanisms of resistance in Brassica carinata, B. napus and B. juncea to Pseudocercosporella capsellae. Plant Pathology, 65(6): 888900. DOI: https://doi.org/10.1111/ppa.12484.

39. Hiruma, K., Fukunaga, S., Bednarek, P., PiślewskaBednarek, M., Watanabe, S., Narusaka, Y., Shirasu, K. and Takano, Y. (2013). Glutathione and tryptophan metabolism are required for Arabidopsis immunity during the hypersensitive response to hemibiotrophs. Proceedings of the National Academy of Sciences of the United States of America, 110(23): 9589-9594. DOI: https://doi.org/10.1073/ pnas. 1305745110.

40. Hiruma, K., Onozawa-Komori, M., Takahashi, F., Asakura, M., Bednarek, P., Okuno, T., SchulzeLefert, P. and Takano, Y. (2010). Entry modedependent function of an indole glucosinolate pathway in Arabidopsis for nonhost Resistance against anthracnose pathogens. The Plant Cell, 22:24292443. DOI:10.1105/tpc. 110.074344 .

41. Holmes, G. (2003). Club rot of crucifers (Plasmodiophora brassicae) Woronin. California Polytechnic State University at San Luis Obispo, USA. Available online: https://www.forestryimages.org/ browse/detail.cfm?imgnum $=5513019$. Accessed on 16 March 2019.

42. Holmes, G. (2010). White spot Pseudocercosporella capsellae (Ellis and Everh.) Deighton. California Polytechnic State University at San Luis Obispo, USA. Available online: https://www.ipmimages.org/browse/ detail.cfm?imgnum=1577988. Accessed on $16 \mathrm{March}$ 2019

43.Holst, B. and Fenwick, G.R. (2003). Glucosinolates. In: Encyclopaedia of Food Sciences and Nutrition (Second Edition). Academic Press. Pp2922-2930.

44. Horbach, R., Navarro-Quesada, A. R., Knogge, W. and Deising, H. B. (2011). When and how to kill a plant cell: infection strategies of plant pathogenic fungi. Journal of Plant Physiology, 168(1), 51e62. DOI:10.1016/j.jplph.2010.06.014

45.Hossain, M.S., Ye, W., Hossain, M.A., Okuma, E., Uraji, M., Nakamura, Y., Imori, I.C. and Murata, Y. (2013). Glucosinolate degradation products, isothiocyanates, nitrites and thiocyanates induced stomatal closure accompanied by peroxidase-mediated reac- 
tive oxygen species production in Arabidopsis thaliana. Bioscience, Biotechnology and Biochemistry, 77 (5):977-983. DOI: https://doi.org/10.1271/bbb.120928

46.Hsu, C.L., Juan, H.F. and Huang, H.C. (2015). Functional analysis and characterization of differential coexpression networks. Scientific Reports 5, 13295.

47. Huckelhoven, R. and Panstruga, R. (2011). Cell biology of the plant-powdery mildew interaction. Current Opinion in Plant Biology, 14(6):738e746. DOI: 10.1016/j.pbi.2011.08.002.

48.Islam, M.N. and Guest, D. (2010). Brassica root and shoot glucosinolate levels: Interaction with Clubroot disease cycle. MSc Thesis, Faculty of Agriculture, Food and Natural Resources, The University of Sydney, Australia. $89 p$

49.Jiang, Z., Dong, X.B., Li, Z.H., He, F. and Zhang, Z. (2016). Differential coexpression analysis reveals extensive rewiring of Arabidopsis gene coexpression in response to Pseudomonas syringae infection. Scientific Reports, DOI: 10.1038/srep35064.

50.Johansson, O. N., Fantozzi, E., Fahlberg, P., Nilsson, A. K., Buhot, N., Tor, M., and Andersson, M. X. (2014). Role of the penetration-resistance genes PEN1, PEN2 and PEN3 in the hypersensitive response and race-specific resistance in Arabidopsis thaliana. Plant Journal, 79: 466-476. DOI: 10.1111/ tpj.12571.

51.Jones, J.D.G. and Dangl, J.L. (2006). The plant immune system. Nature, 444(16): 323-329. DOI:10.1038/nature05286

52.Khokon, M.D.A.R., Jahan, M.D.S., Rahman, T., Hossain, M.A., Muroyama, D., Minami, M., Munemasa, S., Mori, I.C., Nakamura, Y. and Murata, Y. (2011). Allyl isothiocyanate (AITC) induces stomatal closure in Arabidopsis. Plant, Cell and Environment, 34:1900-1906. DOI: 10.1111/j.13653040.2011.02385.x

53.Klein, A.P. and Sattely, E.S. (2017). Biosynthesis of cabbage phytoalexins from indole glucosinolate. Proceedings of the National Academy of Sciences of the United States of America (PJAS), 14(8):19101915. DOI: https://doi.org/10.1073/pnas.1615625114.

54.Koch, E. and Slusarenko, A. (1990). Arabidopsis is susceptible to infection by a downy mildew fungus. Plant Cell, 2(5):437-445.

55.Koike, S.T., Gladders, P, and Paulus, A.O. (2007). Vegetable Diseases: A Color Handbook. San Diego, CA, USA: Academic Press.

56.Ku, K.M., Becker, T.M. and Juvik, J.A. (2016). Transcriptome and metabolome analyses of glucosinolates in two broccoli cultivars following jasmonate treatment for the induction of glucosinolate defense to Trichoplusia ni (Hübner). International Journal of Molecular Science, 17,1135. DOI:10.3390/ ijms17071135.

57.Kus'nierczyk, A., Winge, P., Midelfart, H., Armbruster, W.S., Rossiter, J.T. and Bones, A.M. (2007). Transcriptional responses of Arabidopsis thaliana ecotypes with different glucosinolate profiles after attack by polyphagous Myzus persicae and oligophagous Brevicoryne brassicae. Journal of Experimental Botany, 58(10):2537-2552. DOI: https:// doi.org/10.1093/jxb/erm043

58.Lambrix, V., Reichelt, M., Mitchell-Olds, T., Kliebenstein, D. J. and Gershenzon, J. (2001). The Arabidopsis epithiospecifier protein promotes the hydrolysis of glucosinolates to nitriles and influences Tri- choplusia ni herbivory. The Plant Cell, 13(12):27932807. DOI: https://doi.org/10.1105/tpc.010261

59.Lazarev, A.M. (2009). Diseases: Pseudomonas syringae pv. maculicola (McCullock) Young et al - bacteria leaf spot of cauliflower. Interactive Agricultural Ecological Atlas of Russia and Neighbouring Countries. Economic plant and their diseases, pest and weeds. Available online: http://www.agroatlas.ru/en/ content/diseases/Brassicae/

Brassicae_Pseudomonas_syringae_pv_maculicola/ index.html. Accessed on 16 March $201 \overline{9}$.

60.Lehmann, S., Serrano, M., L'Haridon, F., Tjamos, S. E., and Metraux, J. P. (2015). Reactive oxygen species and plant resistance to fungal pathogens. Phytochemistry, 112:54-62.

61.Mathur, P., Sharma1, E., Singh, S.D., Bhatnagar1, A.K., Singh, V.P. and Kapoor, R. (2013). Effect of elevated $\mathrm{CO}_{2}$ on infection of three foliar diseases in oilseed Brassica Juncea. Journal of Plant Pathology, 95(1):135-144. DOI: http://dx.doi.org/10.4454/ JPP.V95I1.013.

62.Mauch F, Torche S, Schläppi K, Branciard L, Belhaj K, Parisy V, and Si-Ammour A. (2009). Phytophthora brassicae as a pathogen of Arabidopsis. In Oomycete Genetics and Genomic: Diversity, Interactions and Research Tools Edited by: Lamour K, Kamoun S. Wiley-Blackwell :333-345

63.Meena, P.D., Awasthi, R.P., Chattopadhyay, C., Kolte, S.J. and Kumar, A. (2010). Alternaria blight: a chronic disease in rapeseed-mustard. Journal of Oilseed Brassica, 1(1):1-11.

64.Mikkelsen, M.D., Olsen, C.E. and Halkier B.A. 2010). Production of cancer-preventive glucoraphanin in tobacco. Molecular Plant, 3(4):751-759. DOI: https:// doi.org $/ 10.1093 / \mathrm{mp} / \mathrm{ssq020}$

65.Moussaieff, A., Rogachev, I., Brodsky, L., Malitsky, S., Toal, T.W., Belcher, H., Yativ, M., Brady, S.M., Benfey, P.N. and Aharoni, A. (2013). High-resolution metabolic mapping of cell types in plant roots. Proceedings of the National Academy of Sciences, 110 (13) E1232-E1241; DOI:10.1073/ pnas. 1302019110

66.Mullen, J. (2012). Black rot of crucifers Xanthomonas campestris pv. Campestris (Pammel 1895) Dowson 1939. Auburn University, Alabama, USA. Available online: https://www.forestryimages.org/browse/ detail.cfm?imgnum=1568130. Accessed on 16 March 2019.

67.Osbourn, A. E. (1996). Preformed antimicrobial compounds and plant defense against fungal attack. The Plant Cell, 8(10):1821.

68.Pangesti, N., Reichelt, M., van de Mortel, J.E., Kapsomenou, E., Gershenzon, J., van Loon, J.J.A., Dicke, M. and Ana Pineda, A. (2016). Jasmonic acid and ethylene signaling pathways regulate glucosinolate levels in plants during rhizobacteria-induced systemic resistance against a leaf-chewing herbivore. Journal of Chemical Ecology, 42:1212-1225, DOI: 10.1007/s10886-016-0787-7.

69.Pétriacq, P., Ton, J., Patrit, O., Tcherkez, G. and Gakière, B. (2016). NAD acts as an integral regulator of multiple defense layers. Plant Physiology, DOI:10.1104/pp.16.00780.

70.Petrie, G.A., Mortensen, K. and Dueck, J. (1985). Blackleg and other diseases of rapeseed in Saskatchewan, 1978 to 1981. Canadian Plant Disease Survey, 65:35-41. 
71.Pfalz, M., Mikkelsen, M.D., Benarek, P., Olsen, C.E., Halkier, B.A. and Kroymann, J. (2011). Molecular engineering in Nicotiana benthamiana reveals key enzyme functions in Arabidopsis indole glucosinolate modification. The Plant Cell, 23:716-729. DOI: https://doi.org/10.1105/tpc.110.081711.Pscheidt, J.W., and Ocamb, C.M. (2019). Pacific Northwest Plant Disease Management Handbook. Available online: https://pnwhandbooks.org/node/3637/print. Accessed on 16 March 2019.

72.Rausher, M.D. (2001). Co-evolution and plant resistance to natural enemies. Nature, 411:857-864.

73.Redovnikovic, I.R., Glivetic, T., Delonga, K. and Vorkapic-Furac, J. (2008). Glucosinolates and their potential role in plant. Periodicum Biologorum, 110 (4): 297-309.

74.Saavedra, M.J., Borges, A., Dias, C., Aires, A., Bennett, R.N. Rosa, E.S. and Simões, M. (2010). Antimicrobial activity of phenolics and glucosinolate hydrolysis products and their synergy with streptomycin against pathogenic bacteria. Medicinal Chemistry, 6:174-183. DOI : 10.2174/1573406411006030174

75.Schlaeppi, K., Abuo-Mansour, E., Buchala, A. and Mauch, F. (2010). Disease resistance of Arabidopsis to Phythophthora brassicae is established by the sequential action of indole glucosinolates and camalexin. The Plant Journal, 63:840-851. DOI: https://doi.org/10.1111/j.1365-313X.2010.04197.x

76.Schlaeppi, K., Bodenhausen, N., Buchala, A., Mauch, F., and Reymond, P. (2008). The glutathione -deficient mutant pad2-1 accumulates lower amounts of glucosinolates and is more susceptible to the insect herbivore Spodoptera littoralis. The Plant Journal, 55(5):774-786. DOI: https://doi.org/10.1111/ j.1365-313X.2008.03545.xSemb, L. (1971). A rot of stored cabbage caused by a Phytophthora sp. Acta Horticulturae, 20:32-35.

77.Shlezinger, N., Minz, A., Gur, Y., Hatam, I., Dagdas, Y. F., Talbot, N. J., and Sharon, A. (2011). Antiapoptotic machinery protects the necrotrophic fungus Botrytis cinerea from host-induced apoptotic-like cell death during plant infection. PLoS Pathogens, 7(8), e1002185. DOI: https://doi.org/10.1371/ journal.ppat. 1002185

78.Smith, J.D., Woldemariam, M.G., Mescher, M.C., Jander, G. and De Moraes, C.M. (2016). Glucosinolates from host plants influence growth of the parasitic plant Cuscuta gronovii and its susceptibility to herbivores. Plant Physiology, pp-00613. DOI: https:// doi.org/10.1104/pp.16.00613

79.Song T, Chu M, Lahlali R, Yu F and Peng G (2016). Shotgun label-free proteomic analysis of clubroot (Plasmodiophora brassicae) resistance conferred by the gene Rcr1 in Brassica rapa. Frontiers in Plant Science, 7:1013. DOI: 10.3389/fpls.2016.01013

80.Sotelo, T., Lema, M., Soengas, P., Cartea, M.E. and Velasco, P. (2014). In vitro activity of glucosinolates and their degradation products against Brassicapathogenic bacteria and fungi. Applied and Environmental Microbiology, 81(1):432- 440.DOI:10.1128/ AEM.03142-14.

81.Stahl, E., Bellwon, P., Huber, S., Schlaeppib, K., Bernsdorff, F., Vallat-Michel, A., Mauchb, F. and Zeiera, J. (2016). Regulatory and functional aspects of indolic metabolism in plant systemic acquired resistance. Molecular Plant, DOI: 10.1016/ j.molp.2016.1.005
82.Stotz, H.U., Sawada, Y., Shimada, Y., Hirai, M.Y., Sasaki, E., Krischke, M., Brown, P.D., Saito, K., and Kamiya, Y. (2011). Role of camalexin, indole glucosinolates, and side chain modification of glucosinolatederived isothiocyanates in defense of Arabidopsis against Sclerotinia sclerotiorum. The Plant Journal, 67:81-93. DOI: https://doi.org/10.1111/j.1365313X.2011.04578.x

83.Szczygłowska, M., Piekarska, A., Konieczka, P. and Namieśnik, J. (2011). Use of brassica plants in the phytoremediation and biofumigation processes. International Journal of Molecular Sciences, 12: 7760 7771. DOI:10.3390/ijms 12117760

84.Tierens, K. F. J., Thomma, B. P., Brouwer, M., Schmidt, J., Kistner, K., Porzel, A., ... \& Broekaert, W. F. (2001). Study of the role of antimicrobial glucosinolate-derived isothiocyanates in resistance of Arabidopsis to microbial pathogens. Plant Physiology, 125(4):1688-1699. DOI: 10.1104/pp.125.4.1688.

85.Ton, J., Flors, V., and Mauch-Mani B, (2009). The multifaceted role of $A B A$ in disease resistance. Trends in Plant Science, 14:310-317. DOI: https:// doi.org/10.1016/j.tplants.2009.03.006

86.Torres, M.A., Jones, J.D.G. and Dangl, J.L. (2006). Reactive oxygen species signaling in response to pathogens. Plant Physiology, 141:373-378. DOI: https://doi.org/10.1104/pp.106.079467

87.Ugolini, L., Martini, C., Lazzeri, L., D’Avino, L. and Mari, M. (2014). Control of postharvest grey mould (Botrytis cinerea Per.: Fr.) on strawberries by glucosinolate-derived allyl-isothiocyanate treatments. Postharvest Biology and Technology, 90:34-39. DOI: https://doi.org/10.1016/j.postharvbio.2013.12.002

88. Underwood, W. (2012). The plant cell wall: a dynamic barrier against pathogen invasion. Frontiers in Plant Science, 3, 85. DOI: 10.3389/fpls.2012.00085

89.Velasco, P., Lema, M., Francisco, M., Soengas, P. and Cartea, M.E. (2013). In vivo and in vitro effects of secondary metabolites against Xanthomonas campestris pv. Campestris. Molecules, 18:11132-11143. DOI: https://doi.org/10.3390/molecules180911131

90.Vicente, J.G. and Holub, E.B. (2013) Xanthosoma campestris pv. Campestris (cause of black rot of crucifers) in the genomic era is still a worldwide threat to brassica crops. Molecular Plant Pathology, 14 (1): 218. DOI: $10.1111 / \mathrm{j} .1364-3703.2012 .00833 . x$

91.Voorrips, R.E. (1995). Plasmodiophora brassicae: aspects of pathogenesis and resistance in Brassica oleracea. Euphysica, 83:139-146.

92.Vwioko, D., Okoekhian, I. and Ogwu, M.C. (2018). Stress Analysis of Amaranthus hybridus L. and Lycopersicon esculentum Mill. Exposed to Sulphur and Nitrogen Dioxide. Pertanika Journal of Tropical Agricultural Science, 41(3):1169-1191

93.Wang, Y., Bouwmeester, K., Van De Mortel, J.E., Shan, W. and Govers, F. (2013a). A novel Arabidopsis-oomycete pathosystem: differential interactions with Phytophthora capsici reveal a role for camalexin, indole glucosinolates and salicylic acid in defence. Plant, Cell and Environment, 36:1192-1203. DOI: https://doi.org/10.1111/pce.12052

94.Wang, Y., Bouwmeester, K., Van De Mortel, J.E., Shan, W. and Govers, F. (2013b). Induced expression of defense-related genes in Arabidopsis upon infection with Phythophthora capsici. Plant Signaling and Behavior, 8:e24618. DOI: https://doi.org/10.4161/ psb.24618 
95.Wells, B.C. (2018). Disease notes: Alternaria leaf spot of Brassica crops. UF/IFAS University of Florida, USA. Available online: http://blogs.ifas.ufl.edu/ stjohnsco/2018/03/21/disease-notes-alternaria-leafspot-brassica-crops/. Accessed on 16 March 2019.

96.Williamson, B., Tudzynski, B., Tudzynski, P. and van Kan, J. A. (2007). Botrytis cinerea: the cause of grey mould disease. Molecular Plant Pathology, 8(5):561580. DOI: https://doi.org/10.1111/j.1364-3703.20 07.00417.xWittstock, U., and Burow, M. (2010). Glucosinolate breakdown in Arabidopsis: mechanism, regulation and biological significance. The Arabidopsis Book 8: e0134, doi/10.1199/tab.0134.

97.Xu, J., Meng, J., Meng, X., Zhao, Y., Liu, J., Sun, T. and Zhang, S. (2016). Pathogen-responsive MPK3 and MPK6 reprogram the biosynthesis of indole glucosinolates and their derivatives in Arabidopsis immunity. The Plant Cell, 28(5):1144-1162. DOI: https:// doi.org/10.1105/tpc.15.00871

98.Young, J.M. (2010). Taxonomy of pseudomonas syringae. Journal of Plant Pathology, 92(1): S1.55-
S1.14.

99.Zhang, W., Kwon, S.T., Chen, F. and Kliebenstein, D.J. (2016). Isolate dependency of Brassica rapa resistance QTLs to Botrytis cinerea. Frontiers in Plant Science, 7:161. DOI: 10.3389/fpls.2016.00161

100.Zhao Y, Bi K, Gao Z, Chen T, Liu H, Xie J, Cheng J, Fu $Y$ and Jiang D (2017). Transcriptome analysis of Arabidopsis thaliana in response to Plasmodiophora brassicae during early infection. Frontiers in Microbiology, 8:673, DOI: 10.3389/fmicb.2017.00673

101.Zhao, Y., Hull, A.K., Gupta, N. R., Goss, K. A., Alonso, J., Ecker, J.R., Normanly, J., Chory, J., and Celenza, J.L. (2002). Trp-dependent auxin biosynthesis in Arabidopsis: involvement of cytochrome P450s CYP79B2 and CYP79B3. Genes Development, 16:3100-3112. DOI:10.1101/gad.1035402

102.Zhou, X.J., Lu, S., Xu, Y.H, Wang, J.W. and Chen, X.Y. (2002). A cotton cDNA (GaPR10) encoding a pathogenesisrelated to protein with in vitro ribonuclease activity. Plant Science, 162: 629-636.DOI:https:// doi.org/10.1016/S0168-9452(02)00002-X 